\title{
Total polyphenol content and antioxidant activity of commercial Noni (Morinda citrifolia L.) juice and its components
}

\author{
Adriana Bramorski, Adriana da Rosa Cherem*, Chaiana Paula Marmentini, Joseane Torresani, \\ Tatiana Mezadri, Andréa de Almeida Silva Costa
}

Laboratory of Bromatology, Course of Nutrition, Center of Sciences of the Health, University of Vale of Itajai

\begin{abstract}
The plant Morinda citrifolia L. (noni) has been the focus of many recent studies due to its potential effects on treatment and prevention of several diseases. However, there are few in vivo and in vitro studies concerning its composition and antioxidant capacity. The aim of the present study was to determine the total polyphenol content (TPC) and antioxidant capacity of a juice commercialized as noni juice, but containing grape, blueberry and noni fruits. Commercial noni juice was compared against its separate constituents of blueberry and grape juice. Folin-Ciocalteu and DPPH $\bullet$ methods were used to determine the concentration of total polyphenol content and antioxidant activity, respectively. Commercial noni juice presented higher values of TPC (91.90 mg of gallic acid/100 mL juice) and antioxidant activity $(5.85 \mathrm{mmol} / \mathrm{L})$ compared to its $5 \%$ diluted constituents. Concentrated blueberry juice presented higher TPC and antioxidant activity than the other juices analyzed. Considering that the blueberry and grape juices account for only $10 \%$ in the composition of commercial noni juice, it can be inferred that these two components contribute significantly to the antioxidant activity. Therefore, additional studies are necessary in order to elucidate the contribution of the noni juice as an antioxidant.
\end{abstract}

Uniterms: Noni juice/antioxidant activity. Morinda citrifolia L. Total polyphenols/determination. Antioxidants.

\begin{abstract}
A planta Morinda citrifolia L. tem sido objeto de muitas pesquisas decorrente de seus efeitos benéficos no tratamento e prevenção de muitas doenças. No entanto, são escassos os estudos in vivo e in vitro sobre os compostos presentes e sua capacidade de atuar como antioxidante. Objetivou-se com este trabalho determinar o índice de polifenóis totais (IPT) e a capacidade antioxidante do suco de noni comercial, constituído de uva, mirtilo e a fruta do noni. O suco de noni comercial foi comparado com seus constituintes (mirtilo e suco de uva) separadamente. Os métodos Folin-Ciocalteu e DPPH• foram utilizados para determinar a concentração de polifenóis totais e capacidade antioxidante, respectivamente. O suco de noni apresentou valores superiores de IPT (91,90 mg ácido gálico/100 mL de suco) e atividade antioxidante $(5,85 \mathrm{mmol} / \mathrm{L})$ quando comparado aos seus constituintes diluídos a $5 \%$. O suco de mirtilo, na sua forma concentrada, apresentou IPT e atividade antioxidante superior aos demais sucos. Considerando que os sucos de mirtilo e de uva representam apenas $10 \%$ na composição do suco de noni, pode-se inferir que estes dois constituintes contribuem de forma significativa para a atividade antioxidante. Assim, estudos adicionais são necessários para elucidar a contribuição do suco de noni como sequestrador de radicais livres.
\end{abstract}

Unitermos: Suco de noni/atividade antioxidante. Morinda citrifolia L. Polifenóis totais/determinação. Antioxidantes.

\section{INTRODUCTION}

Popular medicine has been using natural and herbal

"Correspondence: A. R. Cherem. Laboratório de Bromatologia, Curso de Nutrição, Centro de Ciências da Saúde, Universidade do Vale do Itajaí. Rua Percy João de Borba, 83 - Trindade - 88036-200 - Florianópolis - SC, Brasil. E-mail: adri.cherem@hotmail.com products for centuries in all cultures of the world. Scientific community and health professionals have shown an increasing interest in research investigating the therapeutic benefits related to these products. Among the widely used medicinal plants, is Morinda citrifolia L. (noni), which was discovered 2000 years ago by ancient Polynesians (Wang et al., 2002; Zin, Hamid, Osman, 2002). 
Recently, this plant has been the focus of several studies due to its nutraceutical properties (Chan-Blanco et al., 2006; Dixon et al., 1999; Zin et al., 2006). The beneficial health effects observed might result from specific compounds extracted from the roots, leafs, peel and fruit such as nitric oxide, alkaloids and sterols with antioxidant potential (Chan-Blanco et al., 2006).

Studies on antioxidants have reported the use of isolated nutrients in the treatment and prevention of diseases. However, a large variety of compounds that can act synergistically in protecting cells and tissues are found in foods (Bianchi, Antunes, 1999).

Phenolic compounds such as flavonoids are the most active and common antioxidants present in fruit and vegetables (Nijveldt et al., 2001). These compounds have an antioxidant function which result from a combination of chelating properties and scavenging of free radicals as well as inhibition of oxidases and other enzymes (Alonso et al., 2004; Trueba, 2003).

According to Wang et al. (2002) juice of noni has been consumed as a medicinal alternative for many diseases such as arthritis, diabetes, high arterial pressure, headaches, AIDS, cancer, peptic ulcer, and others.

Given wide use of this fruit in an array of products in different countries, in vitro and in vivo studies elucidating its therapeutic and nutritional properties have become important.

Commercial noni juice is traditionally made by fermentation of noni fruits in sealed containers for 2 months at ambient temperature (Nelson, 2006). Fresh noni juice is made by direct squeezing of noni fruits (Nelson, 2006). Some noni juice is made by boiling of noni fruits for hours. Since noni is considered a fruit with a bitter taste, addition of sweet tasting components allow changes in organoleptic aspects, favoring the commercialization of noni juice.

Considering the increase in commercialization of this product and the lack of scientific studies regarding the composition of noni juice and its beneficial implications in treatment of diseases, the aim of the present study was to determine the total polyphenols content (TPC), and antioxidant capacity of commercial noni juice and its components.

\section{MATERIAL AND METHODS}

\section{Samples}

Samples of noni juice were acquired through a distributer from the southern region of Brazil. Because this juice comprises $5 \%$ blueberry juice and grape juice, these two products were also acquired in order to perform the present study. Blueberry juice was purchased at a store of natural products in the United States and grape juice from local markets.

Trolox (6-hydroxy-2,5,7,8-tetramethylchroman-2carboxylic acid 97\%) (Sigma-Aldrich Chemical $\mathrm{Co}^{\circledR}$ ) was used as the reference antioxidant and DPPH $\bullet$ (2,2-diphenyl-1-picrylhydrazyl) (Sigma-Aldrich Chemical $\mathrm{Co}^{\circledR}$ ) was used as a free radical and both were used to determine the antioxidant activity. Total polyphenol content was determined using the Folin-Ciocalteu $\left(\right.$ Merck $\mathrm{KGaA}^{\circledR}$ ) reagent.

Spectrophotometric readings were determined using a Shimadzu 1601® UV spectrophotometer. All analyses were carried out in the Food Science Laboratory in Nutrition of the University of Vale of Itajaí (UNIVALI), with the collaboration of the Center for Chemical and Pharmaceutical Research, UNIVALI - Itajaí (SC).

\section{Total Polyphenol Content (TPC)}

This method consists of determining the total polyphenol content through oxidation of phenolic compounds using a mix of phosphotungstic and phosphomolybdic acids in base medium, producing blue acids of tungsten and molybdenum. Absorbance of these acids was then read at $765 \mathrm{~nm}$ (Folin, Ciocalteu, 1927; Moyer et al., 2002). Results were expressed in $\mathrm{mg}$ gallic acid/100 mL noni juice. Each assay was performed in triplicate.

\section{Antioxidant Activity - DPPH• Method}

This method is based on decreased absorbance of $\mathrm{DPPH} \cdot$ radical read at $515 \mathrm{~nm}$, due to the action of antioxidants. A $0.1 \mathrm{~mL}$ volume of the sample was added to $3.9 \mathrm{~mL}$ of DPPH dissolved in methanolic solution and carefully homogenized. Free radical was freshly prepared before each assay while protected from light (Villaño et al., 2007). Absorbance was read at $515 \mathrm{~nm}$ at different time intervals until the reaction reached stability. DPPH $\bullet$ concentration was determined by a calibration curve obtained by linear regression (Van Den Berg et al., 1999).

Results were expressed inTEAC (Trolox-equivalent antioxidant capacity, $\mathrm{mmol} / \mathrm{L}$ of sample). In order to determine the TEAC value, two dilutions were carried out in duplicate, considering four absorbance values for calculation. Data were interpolated on a Trolox calibration curve (absorbance variation versus Trolox concentration) and samples were suitably diluted in order to keep their values within the calibration curve. To determine the TEAC value of each assayed solution, the Trolox concentration was multiplied by dilution factor (Van Den Berg et al., 1999). 


\section{Stability of phenolic compounds from noni juice during storage under refrigeration}

Considering the indication of daily consumption of $30-60 \mathrm{~mL}$ of noni juice, the pack was maintained under refrigeration $\left(4^{\circ} \mathrm{C}\right)$ after opening, in order to evaluate possible changes in polyphenol composition during storage. Over a period spanning four weeks, the time taken to use about $1 \mathrm{~L}$ of noni juice, a sample of $30 \mathrm{~mL}$ was collected every week in order to determine the total polyphenol content, according to Folin, Ciocalteu (1927).

\section{Statistical analysis}

Results were expressed as mean \pm standard deviation. Statistical analyses were carried out using Statistica software version 5.0 by applying ANOVA. Significant differences among samples were evaluated by Tukey's test at a significant level of 0.05 .

\section{RESULTS AND DISCUSSION}

\section{Total Polyphenol Content}

Polyphenolic compounds have been implicated in antioxidant activity of fruits, vegetables and derived beverages (Trueba, 2003). Table I shows total polyphenol content (means \pm standard deviation) of noni, blueberry and grape juices.

Data contained in Table I shows that commercial noni juice presented higher values of TPC compared to blueberry and grape juice diluted at $5 \%$. Considering that noni juice constitutes a blend of $5 \%$ of blueberry and grape juice, these two components represent $31.65 \mathrm{mg}$ of total polyphenols. It can be inferred that noni juice corresponds to $65.56 \%$ of total polyphenols against $27.90 \%$ and $6.54 \%$ which represent the $5 \%$ blueberry and grape juice, respectively. Because noni is considered a fruit with a bitter taste, addition of sweet tasting components allow changes in organoleptic aspects, favoring the commercialization of noni juice.
Studies on the chemical composition of noni have reported that phenolic compounds are predominant in the juice, acting as free radicals scavengers and serving to prevent several diseases (Chan-Blanco et al., 2006; Dixon, Mcmillen; Etkin, 1999).

Yang et al (2007) evaluated the polyphenol content and antioxidant activity of noni juice during storage at different temperature. At time zero, fresh noni juice presented polyphenol content of the $210 \mathrm{mg}$ gallic acid/100 $\mathrm{ml}$ - a value higher than that found in the present study. According to the authors, the processing of the noni juice and storage influenced the polyphenol content and antioxidant activity. This could explain the lower results found in the present study.

Su and Silva (2006) evaluated polyphenol content in different kinds of blueberry products (juice, vinegar and wine) and reported that the highest content was found in processed juice from pulp, presenting $29.2 \mathrm{mg}$ EGA/100 $\mathrm{mL}$ juice. In the present study, lower values were found (25.64 mg GA/100 mL juice). However, it should be noted that this occurred in $5 \%$ diluted juice, presenting higher values than the study of Su and Silva (2006) when in its concentrated form.

Furthermore, Malacrida and Motta (2005), evaluating grape juice, reported higher values of total polyphenols (143 $\mathrm{mg} \mathrm{GA} / 100 \mathrm{~mL}$ juice) in original grape juice compared to reconstituted grape juice (105 mg GA/100 mL juice). According to the authors, high temperatures during flavor recovery, evaporation, type of extraction and reactions occurring during juice storage can influence total polyphenol content. Grape juice $5 \%$ diluted used in the present study presented TPC of $6.01 \mathrm{mg} \mathrm{GA} / 100 \mathrm{~mL}$ juice, a value similar to that found by Malacrida and Mottha (2005).

Table 1 shows the total polyphenol content of concentrated juices. It is evident that blueberry juice presented TPC five times higher than noni juice and four times higher than grape juice. However, no significant differences were observed ( $p>0.05)$ between grape and noni juices. Blueberry juice presented statistically significant $(p<0.001)$ values when compared with grape and noni juices.

TABLE I - Means and standard deviation of Total Polyphenol Content of Noni, Blueberry and Grape Juices

\begin{tabular}{lcc}
\hline Sample & TPC $^{*}(\mathrm{mg} \mathrm{GA} / 100 \mathrm{~mL} \text { juice })^{\ddagger}$ & TPC $^{\dagger}(\mathrm{mg} \mathrm{GA} / 100 \mathrm{~mL} \text { juice })^{\ddagger}$ \\
\hline Noni Juice & $91.90 \pm 0.52^{\mathrm{a}}$ & $91.90 \pm 0.52^{\mathrm{a}}$ \\
Blueberry Juice & $25.64 \pm 0.83^{\mathrm{b}}$ & $512.00^{\mathrm{b}}$ \\
Grape Juice & $6.01 \pm 0.85^{\mathrm{c}}$ & $120.00^{\mathrm{a}}$ \\
\hline
\end{tabular}

* TPC: Total Polyphenol Content of commercial noni juice (5\% blueberry; grape juice) ${ }^{\dagger}$ TPC: Total Polyphenol Content of commercial noni juice ( $5 \%$ blueberry; grape juice) and its components in its concentrated form. Different letters in the same column indicate significant difference $(\mathrm{P}>0.05)$ Results expressed in $\mathrm{mg}$ gallic acid/100 $\mathrm{mL}$ juice. 
TABLE II - Means and standard deviations of antioxidant activity of noni, blueberry and grape juices

\begin{tabular}{lcc}
\hline Sample & ${\text { DPPH• } *(\mathrm{mmol} / \mathrm{L} \text { juice })^{\ddagger}}^{\ddagger}$ & DPPH• $^{\dagger}(\mathrm{mmol} / \mathrm{L} \text { juice })^{\ddagger}$ \\
\hline Noni juice & $5.85 \pm 2.24^{\mathrm{a}}$ & $5.85 \pm 2.24^{\mathrm{a}}$ \\
Blueberry juice & $1.72 \pm 0.11^{\mathrm{b}}$ & $34.40^{\mathrm{b}}$ \\
Grape juice & $0.37 \pm 0.02^{\mathrm{c}}$ & $7.40^{\mathrm{a}}$ \\
\hline
\end{tabular}

* DPPH•: 2,2-diphenyl-1-picrylhydrazyl. Antioxidant activity of commercial noni juice and of 5\% diluted grape and blueberry juices. ${ }^{\dagger}$ DPPH $\bullet$ : Antioxidant activity of commercial juice noni, blueberry and grape concentrated juices. Different letters in the same column indicate significant difference $(\mathrm{P}>0.05)$. ${ }^{\ddagger}$ Results expressed in $\mathrm{mMol} / \mathrm{L}$ juice.

\section{Antioxidant activity}

With the increasing interest in function and diversity of antioxidants, some methods have been developed in order to determine this activity in food, beverages and biological samples (Dávalos, Bartolomé, Gómez-Cordovés, 2005).

Among chemical methods applied to determine the antioxidant activity of a compound, DPPH $\bullet$ (2,2-diphenyl1-picrylhydrazyl) is one of the most used methods because it is practical, fast and stable (Espin et al., 2000).

Mean values and standard deviations of antioxidant activity of noni, blueberry and grape juices are presented in Table II.

Noni juice $(5.85 \mathrm{mmol} / \mathrm{L})$ presented a higher TEAC value than $5 \%$ diluted blueberry $(1.72 \mathrm{mmol} / \mathrm{L})$ and grape $(0.37 \mathrm{mmol} / \mathrm{L})$ juices. Regarding results of antioxidant activity of noni juice and its components, it was observed that $64.27 \%$ of antioxidant activity could be represented by noni juice, and $29.40 \%$ and 6.32 by $5 \%$ diluted blueberry and grape juices, respectively.

Concerning antioxidant activity of concentrated blueberry juice, it can be inferred that this presented antioxidant activity 6 times higher than commercial noni juice and 4.5 times higher than grape juice. On the other hand, no significant differences were observed ( $p>0.05$ ) between grape and commercial noni juices. Blueberry juice presented statistically significant $(\mathrm{p}<0.001)$ values compared to grape and noni juices.

Kuskoski et al. $(2005,2006)$ reported that samples rich in anthocyanins present the highest antioxidant activity. It is important to bear in mind that this correlation does not depend solely on concentration and antioxidant quality but also on its interaction with other compounds and the method used to determine the antioxidant activity.

Blueberry is considered a fruit rich in anthocyanins and antioxidants since it presents particularly high polyphenol content in peel and pulp which confer a protective function to cell wall (Kaur, Kapoor, 2001).

Frankel et al. (1998) and Vinson et al. (1999) repor- ted that in grape juice, the antioxidant activity was similar to that found in red wines. Grape juice contains a higher content of glycosylated phenolic compounds than red wine which, according to Hollman et al. (1995), are more easily absorbed than the respective aglicons. On the other hand, the presence of ethanol in wine increases the absorption of phenolics since it prevents polyphenol precipitation in the digestive tract.

Nevertheless, consumption of grape juice as a source of phenolic compounds can present advantages over wine, in that the lack of ethanol allows juice to be consumed by the majority of people, children included, as well as by those with diseases such as hepatitis (Romero-Pérez et al., 1999).

\section{CONCLUSION}

Commercial noni juice and its components can be considered good sources of polyphenols and antioxidants.

Grape and blueberry concentrated juices presented higher TPC and antioxidant activities than commercial noni juice, contributing significantly to the capacity of free radical scavenging, besides representing a lower cost option.

These results suggest that consumption of commercial noni juice, as well as its components, can have potential beneficial effects on heath. However, additional studies in vitro and in vivo are necessary in order to elucidate and identify other compounds that justify the use of noni juice as a free radical scavenger compared to its components.

\section{REFERENCES}

ALONSO, M.G.; TERESA, S.P.; BUELGA, C.S.; GONZALO, J.C.R. Evaluation of the antioxidant properties of fruits. Food Chem., v.84, p.13-18, 2004.

BIANCHI, M.L.P.; ANTUNES, L.M.G. Radicais livres e os principais antioxidantes da dieta. Rev. Nutr., v.12, p.123130, 1999. 
CHAN-BLANCO, Y.; VAILLANT, F.; PEREZ, A.M.; REYNES, M.; BRILLOUET, J.; BRAT, P. The noni fruit (Morinda citrifolia L.): A review of agricultural research, nutritional and therapeutic properties. J. Food Composition Anal., v.19, p.645-654, 2006.

DÁVALOS, A.; BARTOLOMÉ, B.; GÓMEZ-CORDOVÉS, C. Antioxidant properties of grape juices and vinegars. Food Chem., v.93, p.325-330, 2005.

DIXON, A.R.; McMILLEN, H; ETKIN, N.L. Ferment this: the transformation of Noni, a traditional Polynesian medicine (Morinda citrifolia, Rubiaceae). Ecol. Botany, v.53, p.51$68,1999$.

ESPIN, J.C.; SOLER-RIVAS, C.; WICHERS, H.J.; GARCIAVIGUERA, C. Anthocyanin-based natural colorants: A new source of antiradical activity for foodstuff. J. Agric. Food Chem., v.48, p.1588-1592, 2000.

FOLIN, C.; CIOCALTEU, V. Tyrosine and tryptophan determination in protein. J. Biol. Chem., v.73, p.627-650, 1927.

FRANKEL, E.N.; BOSANEK, C.A.; MEYER, A.S.; SILLIMAN, K.; KIRK, L.L. Commercial grape juice inhibits the in vitro oxidation of human low-density lipoproteins. $J$. Agric. Food Chem., v.46, p.834-838, 1998.

HOLLMAN, P.C.H.; VRIES, J.H.M.; VAN LEEUWEN, S.D.; MENGELERS, M.J.B.; KATAN, M.B. Absorption of dietary quercetin glycosides and quercetin in healthy ileostomy volunteers. Am. J. Clin. Nutr., v.62, p.1276-1282, 1995.

KAUR, C.; KAPOOR, H.C. Review. Antioxidants in fruits and vegetables - the millennium's health. Int. J. Food Sci. Tech., v.36, p.703-725, 2001.

KUSKOSKI, E.M.; ASUERO, A.G.; TRONCOSO, A.M.; MANCINI-FILHO, J.; FETT, R. Aplicación de diversos métodos químicos para determinar actividad antioxidante en pulpa de frutos. Ciênc. Tecnol. Aliment., v.25, p.726732, 2005.

KUSKOSKI, E.M.; ASUERO, A.G.; MORALES, M.T.; FETT, R. Frutos tropicais silvestres e polpas de frutas congeladas: atividade antioxidante, polifenóis e antocianinas. Ciênc. Rural, v.36, p.1283-1287, 2006.
MALACRIDA, C.R.; MOTTA, S da. Compostos fenólicos totais e antocianinas em suco de uva. Ciênc. Tecnol. Aliment., v.25, p.659-664, 2005.

MOYER, R.A.; HUMMER, K.E.; FREI, B.; WROLSTAD, R.E. Anthocyanins, phenolics, and Antioxidants capacity in diverse small fruits: Vaccinium, Rubus, and Ribes. J. Agric. Food Chem., v.50, p.519-525, 2002.

NELSON, S.C. Morinda citrifolia (noni). Species profiles for Pacific Island agroforestry. Available at: <www. tradtionaltree.org>. Accessed on: 12 abr. 2006.

NIJVELDT, R.J.; NOOD, E.; HOORN, D.E.; BOELENS, P.G.; NORREN, K.; LEEUWEN, P.A.M. Flavonoids: a review of probable mechanisms of action and potential applications. Am. Soc. Clin. Nutr., v.74, p.418-425, 2001.

ROMERO-PÉREZ, A.I.; IBERN-GÓMES, M.; LAMUELARAVENTÓS, R.M.; TORRE-BORONAT, M.C. Piceid, the major resveratrol derivative in grape juice. J. Agric. Food Chem., v.47, p.1533-1536, 1999.

SU, M.; SILVA, J.L. Antioxidant activity, anthocyanins, and phenolics of rabbiteye blueberry (Vaccinium ashei) byproducts as affected by fermentation. Food Chem., v.97, p.447-451, 2006.

TRUEBA, G.P. Los flavonoides: antioxidantes e prooxidantes. Rev. Cuba. Invest. Bioméd., v.22, p.48-57, 2003.

VAN DEN BERG, R.; HAENEN, G.R.M.M.;VAN DEN BERG, H.; BAST, A. Applicability of an improved trolox equivalent antioxidant capacity (TEAC) assay for evaluation of antioxidant capacity measurements of mixtures. Food Chem., v.66, p.511-517, 1999.

VILLAÑO, D.; FERNÁNDEZ-PACHÓN, M.S.; MOYÁ, M.L.; TRONCOSO, A.M.; GARCIÁ-PARRILLA, M.C. Radical scavenging ability of polyphenolic compounds towards DPPH• free radical. Talanta, v.71, p.230-235, 2007.

VINSON, J.A.; JANG, J.; YANG, J.; DABBAGH, Y.; LIANG, X.; SERRY, M.; PROCH, J.; CAI, S. Vitamins and especially flavonoids in common beverages are powerful in vitro antioxidants which enrich lower density lipoproteins and increase their oxidative resistance after ex vivo spiking in human plasma. J. Agric. Food Chem., v.47, p.2502-2504, 1999. 
WANG, M.Y.; WEST, B.J.; JENSEN, C.J.; NOWICKI, D.; CHEN, S.; PALU, A.K.; ANDERSON, G. Morinda citrifolia (noni): a literature review and recent advances in noni research. Acta Pharmacol. Sin., v.23, p.1127-1141, 2002.

YANG, J.; PAULINO, R.; JANKE-STEDRONDKY, S.; ABAWI, F. Free-radical-scavenging activity and total phenols of noni (Morinda citrifolia L.) juice and powder in processing and storage. Food Chem., v.102, p.302-308, 2007.
ZIN, Z.M.; HAMID, A.A.; OSMAN, A. Antioxidative activity of extracts from Mengkudu (Morinda citrifolia L.) root, fruit and leaf. Food Chem., v.78, p.227-231, 2002.

ZIN, Z.M.; HAMID, A.A.; OSMAN, A.; SAARI, N. Antioxidative activities of chromatographic fractions obtained from root, fruit and leaf of Mengkudu (Morinda citrifolia L.). Food Chem., v.94, p.169-178, 2006.

Received for publication on $04^{\text {th }}$ March 2009. Accepted for publication on $01^{\text {st }}$ July 2010. 